\title{
Inducible Nitric Oxide Synthase and Proinflammatory Cytokine Expression by Human Keratinocytes during Acute Urticaria
}

\author{
Pierre-André Bécherel,*† Olivier Chosidow, ${ }^{\dagger}$ Liliane Le Goff,* \\ Camille Francès, ${ }^{\dagger}$ Patrice Debré,* M. Djavad Mossalayi,* and \\ Michel Arock* \\ *Department of Immunology (Molecular Immuno-Hematology Group), \\ University of Paris VI, College of Medicine, Paris, France \\ ${ }^{\dagger}$ Department of Dermatology, Pitié-Salpêtrière Hospital, Paris, France
}

\begin{abstract}
Background: IgE/allergen-dependent activation of skin mast cells is involved in acute urticaria and leads to their IL-4 release. Previously we have demonstrated in vitro the induction of the low-affinity receptor for IgE (CD23/ FceRII) in human keratinocytes (HK) upon stimulation with $\mathrm{IL}-4$. In addition, we have observed that ligation of CD23 on keratinocytes induced type II nitric oxide synthase (iNOS), leading to the release of nitric oxide (NO) and proinflammatory cytokines (TNF- $\alpha, \mathrm{IL}-6$ ). According to these in vitro data, we explored whether keratinocytes could also express iNOS, TNF- $\alpha$, IL- 6 , and CD23 in acute urticaria, an in vivo model in which activation of mast cells by IgE/allergen immune complexes is involved.

Materials and Methods: INOS, TNF- $\alpha$, $\mathbb{L}-6$, and CD23 expression by keratinocytes was studied in acute urticaria $(n=11)$ in biopsies from lesional and autologous normal skin by immunohistochemistry, in situ hybridization, or RT-PCR. Nitrites and TNF- $\alpha$ synthesis were assayed in supernatants of cultured lesional keratinocytes.
\end{abstract}

Results: INOS mRNA expression was demonstrated with RT-PCR in 10 biopsies out of 11 sections of acute urticaria lesional skin. Immunohistochemistry showed that this iNOS positivity originated from keratinocytes located close to the dermoepidermal junction; TNF- $\alpha$ and IL- 6 mRNA transcription was observed in all but one iNOS $^{+}$biopsy. Immunostaining and in situ hybridization with CD23-specific probes were strong in all but one iNOS $^{+}$skin biopsy. Noninflamed autologous skin was negative for iNOS (except for a weak positivity in one case), cytokines, and CD23.

Conclusion: The colocalization of iNOS, proinflammatory cytokines, and CD23 within keratinocytes in acute urticaria demonstrates that these cells play an important role in the initiation and maintenance of the inflammatory reaction during this disease in humans through activation of the iNOS pathway by CD23 ligation with IgE/allergen immune complexes.

\section{INTRODUCTION}

Urticaria is a common disorder characterized by eruption of more or less transitory itchy skin swellings in an acute context or which recurs

Address correspondence and reprint requests to: Prof. Michel Arock, Immuno-Hematology Group, Faculté de Médecine de la Pitié-Salpêtrière, Room 510, 91 Boulevard de l'Hôpital, 75013, Paris, France. Phone: (33) 1407797 33; Fax: (33) 1407797 34; e-mail: michel.arock@psl.aphop-paris.fr over a period of weeks to years (1). The larger swellings of angioedema originate subcutaneously or submucosally and may last longer than the wheals. On histopathological examination, the affected skin contains an increased number of mast cells (2). While it is well-established that degranulation of skin mast cells after allergen/ IgE-dependent cross-linking of high-affinity IgE receptors ( $F c \varepsilon R I)$ is involved in acute allergic urticaria, the pathophysiologic features op- 
erative in chronic urticaria are less well understood (3). Recently, serum IgG anti-FceRI autoantibodies with mast cell-activating properties have been described (4-6). Nevertheless, in acute or chronic urticaria, the symptoms are thought to be the consequence of the release of vasoactive mediators from skin mast cells, the most important of which is histamine (7). Urticaria is therefore both an inflammatory and vascular disorder.

Nitric oxide (NO) synthesized from L-arginine by inducible nitric oxide synthase (iNOS) is a multifunctional mediator involved in the vasodilatation observed during inflammatory responses and in the inflammatory reaction itself $(8-11)$. Indeed, we and others have recently demonstrated that the release of proinflammatory cytokines (TNF- $\alpha, \mathrm{IL}-1 \beta, \mathrm{IL}-6$ ) from different human cell types (monocytes, eosinophils, hepatocytes, normal epidermal keratinocytes) is in part dependent upon the nitric oxide pathway $(12,13)$. In vivo, iNOS is involved in many inflammatory diseases, including skin affections such as psoriasis $(14,15)$. The design of NOS inhibitors is now considered of therapeutic interest in the treatment of diseases in which iNOS is overexpressed (16). Here we have tested whether iNOS is expressed in urticaria, accounting for the inflammatory reaction and for the vasodilatation observed. In skin, iNOS induction has been demonstrated in keratinocytes (12). Keratinocytes, the major cellular component of the epidermis, play a pivotal role in the skin immune system in addition to their well-known function as a physical barrier $(17,18)$. We previously showed that iNOS was induced in these cells either after a nonspecific immune stimulation with LPS/IFN- $\gamma(19)$ or after a specific immune stimulation through engagement of surface CD23 (12). CD23, which is mainly defined as the low-affinity receptor for IgE (FceRII), is functionally induced at the surface of keratinocytes upon IL-4 stimulation (12). Because IL-4 is released by activated skin mast cells, $(20,21)$ we investigated whether epidermal keratinocytes expressed not only iNOS and proinflammatory cytokines but also CD23 in urticaria skin lesions.

\section{MATERIALS AND METHODS}

All patients included in this study gave their informed consent before the biopsies. The eleven patients had pink and itchy wheals typical of acute urticaria (Patients 1 to 11 ), lasting less than
$24 \mathrm{hr}$. No etiology was found, except in one patient in whom a penicillin infusion was suspected. In each patient, a typical wheal and healthy skin were biopsied (4-mm punches).

\section{Keratinocyte Isolation and Short-term Culture}

For keratinocyte culture, we used a special serum-free culture medium for human keratinocyte (SFM medium, Gibco-BRL, Cergy-Pontoise, France) supplemented with epidermal growth factor (EGF) and bovine pituitary extracts (both from Gibco-BRL). To extract keratinocytes from skin biopsies (healthy skin and urticaria lesions), the epidermal layer was first separated from the dermis and epidermal pieces were incubated with collagenase (Sigma, St Louis, MO) and trypsin (Biosys, Compiègne, France) (12). When the cells were isolated, they were transferred in plastic dishes coated with collagen type 1 and incubated with the SFM medium devoid of hydrocortisone. Culture supernatants were collected after $48 \mathrm{hr}$. Other cells were immediately lysed in RNA-plus (Bioprobe, Montreuil, France) for RNA extraction.

\section{Inducible NOS mRNA Analysis}

Keratinocytes extracted from healthy skin and urticaria lesions were analyzed for iNOS mRNA transcription. For mRNA isolation, the epidermal sheet was first separated from the dermis as described in the previous section and the cells were then lyzed in RNAplus (Bioprobe, Montreuil sous Bois, France) for $6 \mathrm{hr}$. Total RNA was then extracted as previously described (18). Reverse transcription, semiquantitative mRNA amplification, and visualization of the PCR products were performed exactly as previously described using the following specific primers: iNOS sense $\left(5^{\prime}\right.$ ATGCCAGATGGCAGCATCAGA 3', exon 8, bases 1020-1040), iNOS antisense ( $5^{\prime}$ ACTTC CTCCAGGATGTTGTA 3', exon 11, bases 13711390); HPRT mRNA sense (5' TATGGACAGGA CTGAACGTCTTGC 3') and HPRT (hydroxy phosphoribosyl transferase) mRNA antisense (5' GA CACAAACATGATTCAAATCCCTGA $\left.3^{\prime}\right) \quad(19,22)$. The expected reverse transcription-polymerase chain reaction (RT-PCR) product was $371 \mathrm{bp}$ long for iNOS message and 496 bp long for HPRT message. The molecular weight marker VI (BglIdigested pBR328 DNA + Hinf-1-digested pBR328 DNA; Boehringer-Mannheim) was used. 


\section{Immunostaining}

Frozen skin biopsies (from healthy skin and urticaria lesions) were treated with immunoperoxidase staining LSAB kit (Dako, Levallois-Perret, France). The anti-CD23 monoclonal antibody (MAb) was purified in our laboratory from ascitic fluid of BALB/c mice injected with the hybridoma 135 (23). The anti-iNOS rabbit polyclonal antibody was a kind gift from Dr. Moncada and Dr. Riveros Moreno (Glaxo-Welcome, Beckenham, U.K.). The substrate used for peroxidase was diaminobenzidine. The slides were counterstained with Mayer's hemalun. Positive control and negative control were anti-pancytokeratin $\mathrm{mAb}$ and isotype-matched anti-CD3 mAb, respectively.

\section{In Situ Hybridization}

Probes used were specific for CD23 (700-bp RamHl-Pstl cDNA fragment) (24), TNF- $\alpha$ (430-bp BamHl-EcoRl cDNA fragment) (25), and IL-6 (517-bp Xbal-EcoRl cDNA fragment) (26).

Tissue blocks were cut at $-20^{\circ} \mathrm{C}$ with a microtome knife (Surgipath Medical Industries, Northbrook, IL) in RNAse-free conditions. Tissue sections were dried on the slides and then fixed with $4 \%$ paraformaldehyde. The slides were treated with a detergent (Decon 90, Sigma) and triethoxysilane-3-aminopropyl (Fluka, Paris, France) to decrease nonspecific adherence of probe DNA to the glass. ${ }^{35} \mathrm{~S}$-labeled probes were prepared with $50 \mathrm{ng}$ DNA in $100 \mu \mathrm{l}$ random priming reaction mixture using the Megaprime kit for DNA labeling (Amersham, Amersham Place, England) according to the manufacturer's recommendations. After a l-hr incubation at $37^{\circ} \mathrm{C}$, the reaction was stopped by adding $20 \mathrm{mM}$ ethylenediaminetetraacetic acid (EDTA). The

${ }^{35}$ S-labeled DNA was separated from unbound nucleotides by ethanol precipitation. The material was stored at $-20^{\circ} \mathrm{C}$ until needed.

The sections were rehydrated in phosphate buffer saline (PBS) and digested with $1 \mu \mathrm{g} / \mathrm{ml}$ of proteinase $\mathrm{K}$ in a solution of $2 \mathrm{mM} \mathrm{CaCl}, 10 \mathrm{mM}$ Tris, and $5 \mathrm{mM}$ EDTA for $15 \mathrm{~min}$ at $37^{\circ} \mathrm{C}$. Slides were postfixed in $4 \%$ paraformaldehyde for 5 $\mathrm{min}$, rinsed in glycine $(2 \mathrm{mg} / \mathrm{ml})$ for $10 \mathrm{~min}$, and then dehydrated in graded ethanols. Sections were hybridized for $16 \mathrm{hr}$ at room temperature with $15 \mu$ l of probe mixture per slide. The mixture contained approximately 1-2 $10^{6} \mathrm{cpm}$ of denatured ${ }^{35} \mathrm{~S}$-labeled DNA in $10 \mathrm{mM}$ Tris, $1 \mathrm{mM}$ EDTA, $50 \%$ deionized formamide, $10 \%$ dextran sulfate, $0.6 \mathrm{M} \mathrm{NaCl}, 1 \times$ Denhardt, $20 \mathrm{mM}$ dithiothreitol (DTT), $0.5 \mathrm{mg} / \mathrm{ml}$ tRNA, and $0.25 \mathrm{mg} / \mathrm{ml}$ salmon sperm DNA. Coverslips were rimmed with rubber cement to prevent evaporation. After $16 \mathrm{hr}$ of hybridization, the sealed coverslips were removed and the slides were washed in large volumes of $2 \times$ SSC, followed by a solution containing $10 \mathrm{mM}$ Tris, $\mathrm{pH} 7.4,1 \mathrm{mM}$ EDTA, $600 \mathrm{mM} \mathrm{NaCl}, 10 \mathrm{mM}$ DTT, and $50 \%$ deionized formamide. Sections were then washed twice in $2 \times \mathrm{SSC} / 10 \mathrm{mM}$ DTT, first at $55^{\circ} \mathrm{C}$, then at room temperature, and overnight in a solution of $0.1 \mathrm{M} \mathrm{NaCl}, 10 \mathrm{mM}$ Tris, $1 \mathrm{mM}$ EDTA. Slides were then dehydrated in graded ethanols.

For autoradiography, slides were coated with Kodak NTB-2 emulsion diluted 1:1 in 0.6 M ammonium acetate. After exposure in complete darkness for 7 to 14 days at $4^{\circ} \mathrm{C}$, they were developed in D-19 (Eastman Kodak, Rochester, NY) and fixed in Kodak fixer. The slides were then washed in water and stained with hematoxylin eosin or Mayer's hemalun, and finally mounted with Eukitt (Labonord, Villeneuve d'Ascq, France). For all in situ hybridizations performed in this study, we used a probe specific for actin mRNA as positive control. As a negative control, we applied a probe for mouse IL-3 mRNA on the same biopsies.

\section{Nitrite and TNF- $\alpha$ Assay}

The amount of stable nitrite, the endproduct of NO generated by human keratinocytes, was determined in culture supernatants by the Griess reaction as described elsewhere (27). Briefly, $50 \mu \mathrm{l}$ of culture supernatant from healthy skin or lesional skin was mixed with $150 \mu \mathrm{l}$ of Griess reagent ( $1 \%$ sulfanilamide/ $0.1 \%$ naphtylethylenediamine dihydrochloride) at room temperature for $30 \mathrm{sec}$. Absorbance at $543 \mathrm{~nm}$ was immediately determined on a $V_{\max }$ microplate reader. Nitrite in each tested sample was determined by extrapolation from a sodium nitrite standard curve $(\mu \mathrm{M})$. TNF- $\alpha$ levels were assayed in the same cell supernatants by a specific ELISA (Medgenix, Fleurus, Belgium), the sensibility of which was $13 \mathrm{pg} / \mathrm{ml}$. 


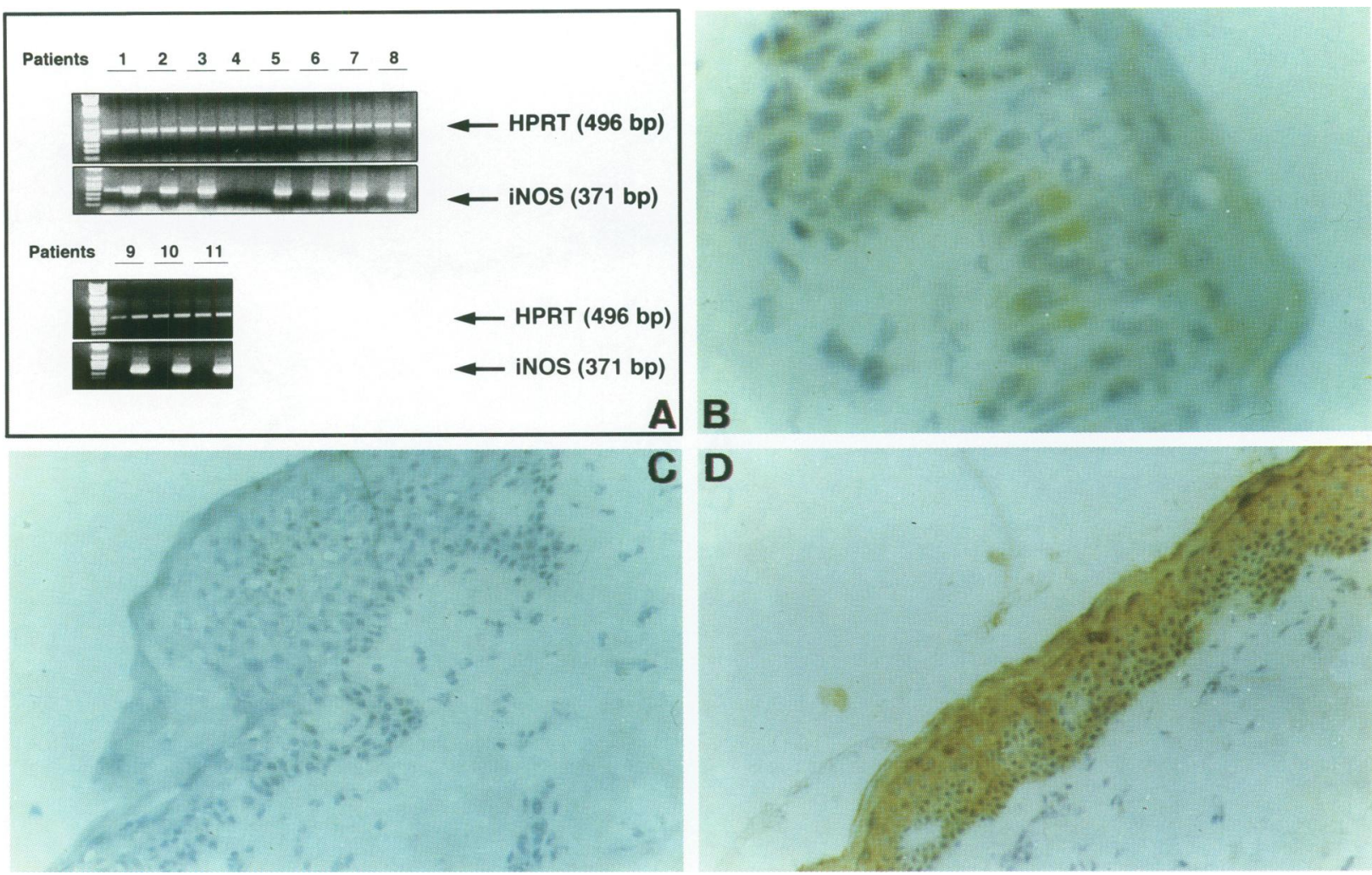

FIG. 1. iNOS expression in healthy and pathological skin

(A) PCR showing HPRT (upper lanes) and iNOS bands (lower bands) in 11 patients with acute urticaria (for each patient: healthy skin followed by lesional skin; Patient 4 is negative for iNOs mRNA). (B) iNOS immunoreactivity in pathological skin, showing staining all along the basal layer of keratinocytes. $(C)$ Negative (anti-CD3 moAb) and (D) positive control (anticytokeratin Ab) from the same biopsy. Magnification: $\times 240$ (B), $\times 60$ (C, D).

\section{RESULTS}

\section{Expression of iNOS mRNA and Protein in Keratinocytes During Urticaria}

RT-PCR analysis of skin biopsies showed a clear expression of iNOS mRNA in 10 out of the 11 patients (Fig. 1A). Patient 4 was iNOS negative. INOS mRNA was not detected in healthy skins, with the exception of that of Patient 1 , which presented a weak positivity. Immunohistochemistry with anti-iNOS antibody further indicated that iNOS was expressed by basal keratinocytes (Fig. 1B). INOS protein was detected in all iNOSmRNA $^{+}$biopsies in inflamed skin, whereas it was negative in healthy skin, even for that of Patient 1, whose RT-PCR was positive. Figure $1 \mathrm{C}$ and $1 \mathrm{D}$ show negative (anti $\mathrm{CD} 3 \mathrm{moAb}$ ) and positive (anticytokeratin $\mathrm{Ab}$ ) control in involved skin biopsies. iNOS expression in urticaria keratinocytes led to the release of significant amounts of nitrites from cells isolated from these skin tissues and short-term cultured ( $48 \mathrm{hr})$ keratinocytes (Table 1). Indeed, in all iNOS-mRNA ${ }^{+}$biopsies,
TABLE 1. Nitrites and TNF- $\alpha$ levels in culture supernatants of keratinocytes extracted from pathological skin

\begin{tabular}{rcc}
\hline Patient & Nitrites $(\boldsymbol{\mu M})$ & TNF- $\alpha(\mathbf{p g} / \mathbf{m l})$ \\
\hline 1 & $6^{a}$ & $42^{a}$ \\
2 & 8 & 54 \\
3 & 8.5 & 80 \\
4 & $<1$ & $<13$ \\
5 & 7.5 & 75 \\
6 & 10 & 95 \\
7 & 4.5 & 40 \\
8 & 9 & 162 \\
9 & 5.5 & 85 \\
10 & 7 & 35 \\
11 & 6 & 48 \\
\hline
\end{tabular}

${ }^{a}$ Levels in culture supernatants of keratinocytes from normal skin were $<1 \mu \mathrm{M}$ and $<13 \mathrm{pg} / \mathrm{ml}$ for nitrites and TNF- $\alpha$, respectively. 

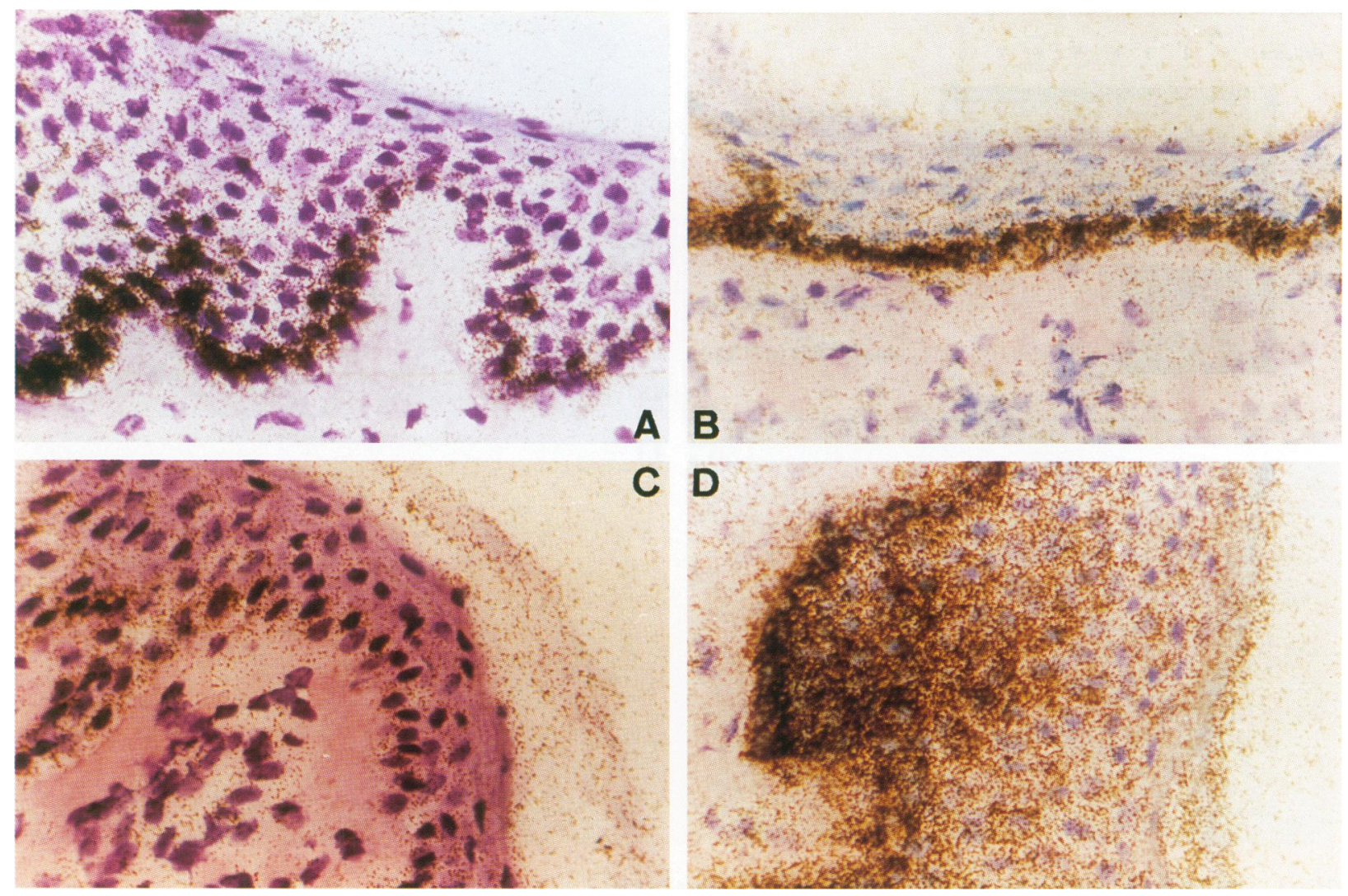

FIG. 2. TNF- $\alpha$ and IL-6 expression in pathological skin

TNF- $\alpha$ (A) and IL-6 (B) mRNA expression demonstrated by in situ hybridization in lesional skin, in the lower layers of the epidermis; (C) negative (mouse IL-3 probe) and (D) positive control (human $\beta$-actin probe) from the same biopsy. Magnification: $\times 240$.

keratinocytes synthesized nitrites that ranged from 3 to $10 \mu \mathrm{M}$. There were no nitrites in iNOS-negative biopsies nor in noninflamed ones, even for Patient 1 .

\section{Expression of TNF- $\alpha$ and IL-6 mRNAs in iNOS-positive Keratinocytes}

TNF- $\alpha$ and IL- 6 mRNAs were present in all but one of the pathological skin biopsies of iNOS $^{+}$ patients (in situ hybridization, Fig. 2A and B) and were located in the basal layers of the epidermis. Healthy skins and iNOS-negative skins were negative. Figure $2 \mathrm{C}$ and $\mathrm{D}$ shows a negative (mouse IL-3 probe) and a positive (human bactin probe) control from lesional skin. As shown in Table 1, TNF- $\alpha$ protein was detected in all supernatants but one of 48 -hr cultured lesional keratinocytes that were positive for TNF- $\alpha$ mRNA. TNF- $\alpha$ levels ranged from 28 to $162 \mathrm{pg} / \mathrm{ml}$.

\section{Expression of CD23 mRNA and Protein in Keratinocytes during Urticaria}

Nine out of 11 patients were positive for CD23 mRNA expression (with a similar distribution to that of iNOS ${ }^{+}$patients). There was therefore a concomitant expression of CD23 and iNOS in nine patients. Messenger RNA positivity was restricted to the first layers of the epidermis, i.e., the basal keratinocytes (Fig. 3A). There was no CD23 mRNA in skin biopsies from healthy skins and positive and negative controls (actin and mouse IL-3 probes) confirmed the specificity of the hybridization (data not shown). Immunohistochemistry with the anti-CD23 mAb confirmed 

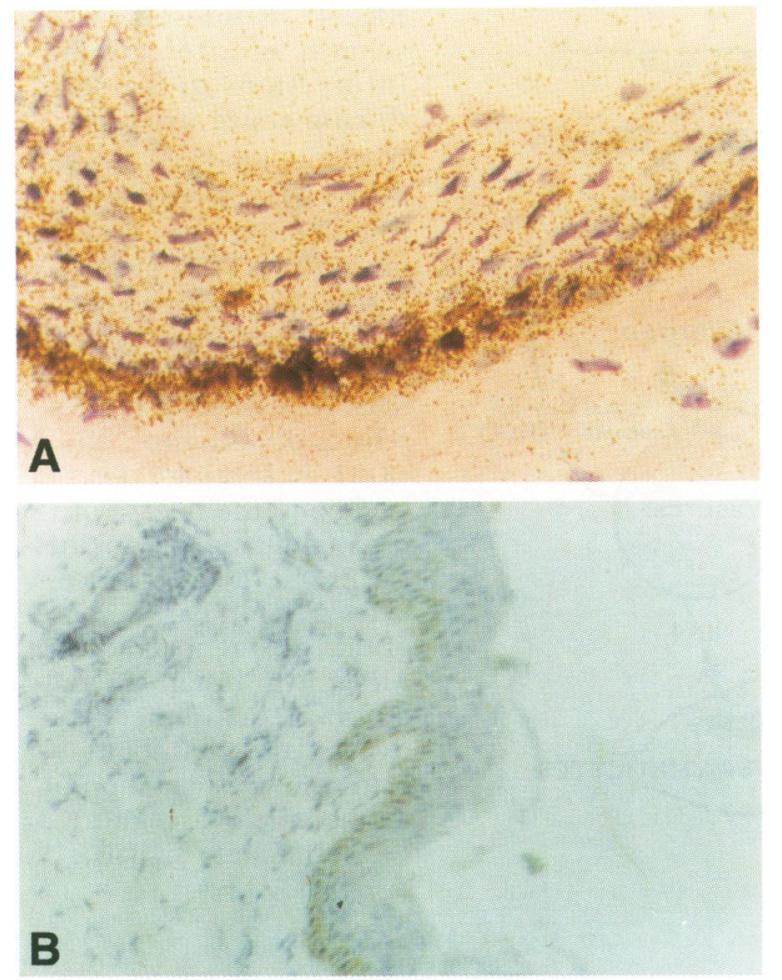

C

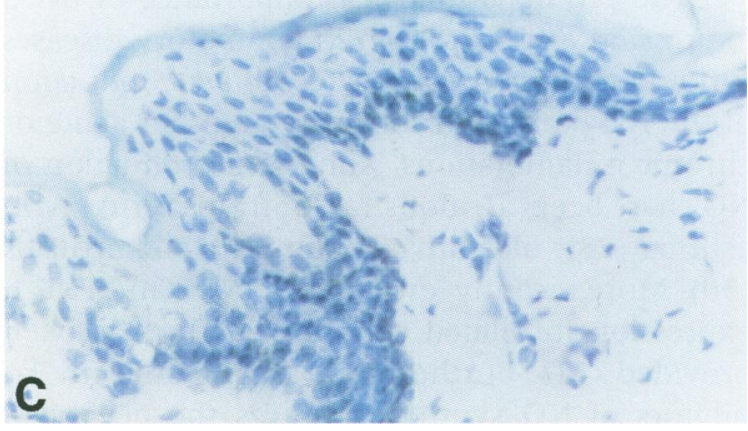

FIG. 3. CD23 expression in normal and pathological skin

(A) CD23 is expressed at the mRNA level in pathological skin as shown by in situ hybridization with a specific probe for human CD23. (B) Immunohistochemistry with anti-CD23 moAb confirms CD23 expression in pathological skin of a patient with acute urticaria. (C) Negativity of the healthy skin of the same patient. Magnification: $\times 60$ (B), $\times 240(\mathrm{~A}, \mathrm{C})$.

the results at the protein level, showing staining mainly on the two first layers of the epidermis (Fig. 3B). Because most of the epidermal cells are keratinocytes, and because our staining was continuous, it is likely that $\mathrm{CD}_{2} 3^{+}$population is mainly constituted of keratinocytes. Healthy skin from the same subjects was negative (Fig. 3C). Positive and negative controls confirmed the specificity of the results (data not shown).

\section{DISCUSSION}

The finding of strong immunoreactivity for iNOS and its colocalization with TNF- $\alpha$, IL-6, and CD23 in keratinocytes from patients with urticaria, may be relevant to the pathogenesis of this disease.

Activation of dermal resident mast cells through high-affinity receptor for IgE (FceRI) is widely implicated in the pathogenesis of urticaria (1). Indeed, many allergens can form immune complexes with IgE in acute urticaria-as infectious agents (bacteria, fungus, parasites), food additives, and antibiotics. In chronic forms, the cause cannot be determined in most cases and it is considered idiopathic. Recently, the presence of autoantibodies against the $\alpha$-chain of FceRI have been identified in up to $25 \%$ of patients suffering from chronic urticaria (6). Whatever the triggering element, the release of vasoactive mediators from activated mast cells, histamine being the most important one, is responsible for the vasodilatation and the dermal edema (7).

Urticaria is actually both an inflammatory and a vascular disease. Nitric oxide is known to have both properties, and among cutaneous cells, keratinocytes seem to be the main target for iNOS induction (12). In this study, we tested the in vivo expression of the NO-synthase pathway in skin during acute urticaria. RT-PCR clearly showed iNOS mRNA expression in lesional skin from 10 out of 11 patients. Furthermore, immunostaining with anti-iNOS antibody was positive in all skin biopsies for which RT-PCR was already positive. It further confirmed that iNOS was mainly expressed in keratinocytes, but not in endothelial cells. INOS mRNA was absent in all healthy skin biopsies except one, which presented a weak positivity. We think that the proximity of the two biopsies in that case (healthy and lesional skin) might explain this paradoxical positivity.

Proinflammatory cytokine (TNF- $\alpha$ and IL-6) synthesis in keratinocytes is partly under the control of the NO pathway (12). We thus investigated whether iNOS ${ }^{+}$keratinocytes could synthesize these cytokines. In almost all pathological skin of iNOS $^{+}$patients, TNF- $\alpha$ and IL- 6 mRNAs were present and also localized in basal keratinocytes.

It is well established that in many different 


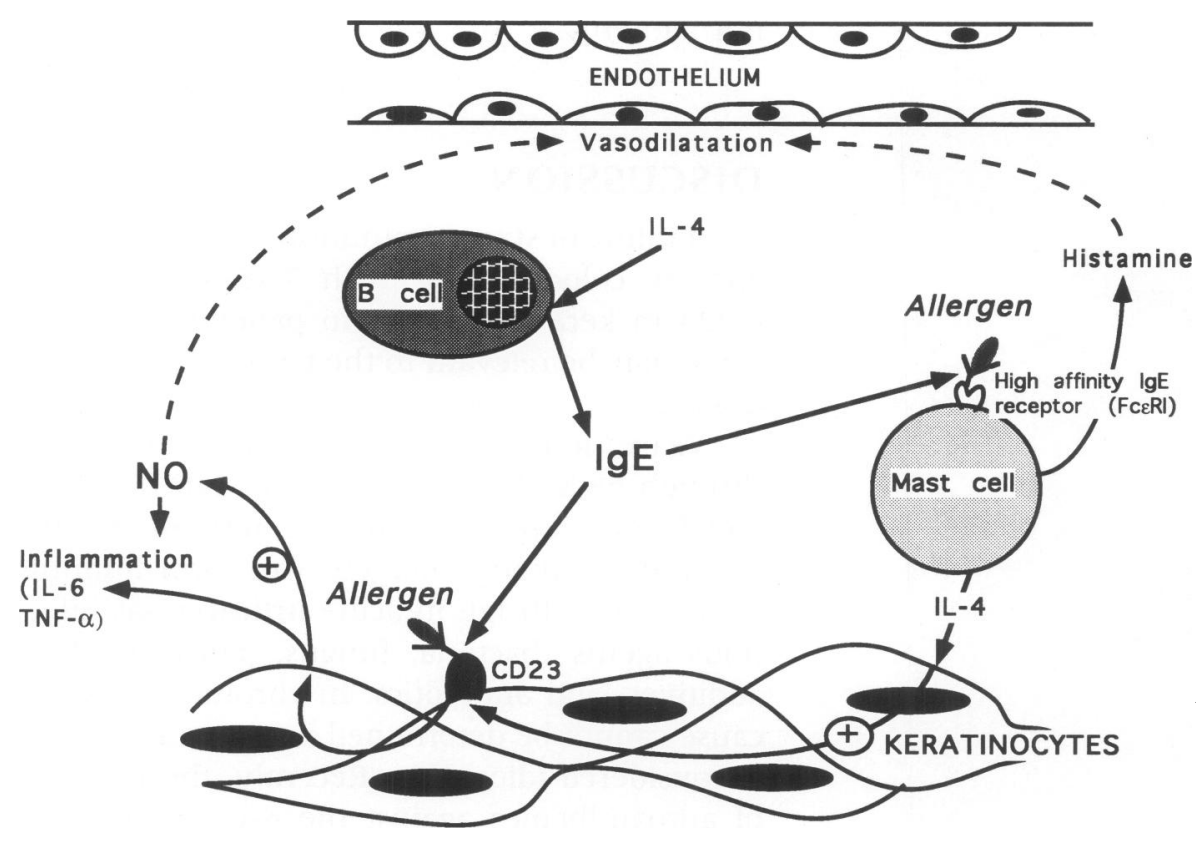

FIG. 4. Proposed scheme of intercellular interactions in the skin during acute urticaria

IL- 4 is synthesized and released from dermal mast cells and induces expression of CD23 (FceRII) at the surface of keratinocytes. IgE/allergen immune complexes can trigger FceRI on mast cells, leading to the release of histamine, and CD23 on keratinocytes, leading to the release of proinflammatory cytokines (TNF- $\alpha$, IL-6). This process takes place in part because of nitric oxide metabolism. Along with histamine and other vasoactive mediators, NO can also contribute toward the vasodilatation of dermal microvasculature $(+$, stimulatory signals). cells a combination of bacterial lipopolysaccharide and cytokines (IFN- $\gamma$ and/or TNF- $\alpha$ and/or IL- $1 \beta$ ) can induce iNOS expression. In a previous study, we demonstrated that ligation of the lowaffinity receptor for IgE (FcERII/CD23) at the surface of keratinocytes was also able to induce the iNOS pathway and subsequently, the release of proinflammatory cytokines from these cells (12). This antigen is induced at the surface of keratinocytes upon incubation with IL-4 (12). IL-4 appears then to be a key cytokine, as it promotes the switch for IgE gene rearrangement in B cells (20) and induces CD23 in human keratinocytes. Activated mast cells also release preformed and newly synthesized IL-4 when stimulated (20). Coexpression of iNOS, TNF- $\alpha$, IL-6, and CD23 in basal keratinocytes during urticaria has led us to propose that IL-4 released after dermal mast cell activation is responsible for the induction of the $\mathrm{CD} 23$ antigen at the surface of very close basal keratinocytes. Ligation of CD23 by IgE/allergen immune complexes may then promote iNOS expression and the production of various cytokines that could act on different skin cell populations (Fig. 4). Further studies should be designed to investigate the expression of iNOS in cases of chronic urticaria due to autoantibodies directed against the $\alpha$-chain of the FceRI. Up until now, FceRI activation by itself has not been shown to induce iNOS expression.
The physiopathological importance of iNOS expression and its role in inflammatory diseases is not limited to keratinocytes. Indeed, induction of the NO pathway contributes to other acute or chronic inflammations. Enhanced production of NO has been demonstrated in patients with asthma (28), ulcerative colitis (29), and arthritis (30). More recently, evidence of iNOS and TNF- $\alpha$ expression in dilated cardiomyopathy has been provided (31). Furthermore, treatment with inhibitors of NO synthase reduces the degree of inflammation and tissue damage in animal models of acute inflammation (32).

The study presented here provides the first evidence of the induction of iNOS in keratinocytes during urticaria, and it further confirms the importance of this enzyme in inflammatory situations. Corticosteroids are used as treatment for severe acute urticarias (33), and these compounds inhibit both iNOS and CD23 expression (12). Other therapeutic agents, such as retinoids, decrease iNOS expression and inflammatory cytokine production in keratinocytes (34). In light of the present data, the design and use of selective inhibitors of the inducible isoform of the nitric oxide synthase enzyme, delivered either through a topical or systemic form, could represent an alternative way of managing patients suffering from severe acute urticaria or resistant chronic forms. 


\section{ACKNOWLEDGMENTS}

We thank Dr. Marc Benhamou for careful reading of the manuscript and helpful advice. This research was supported in part by funds from the Société Française de Dermatologie (Fondation de Recherche en Dermatologie René Touraine) and the Association de Recherche contre le Cancer (ARC).

\section{REFERENCES}

1. Greaves MW. (1995) Chronic urticaria. N. Engl. J. Med. 332: 1767-1772.

2. Natbony S, Philips ME, Elias JM, Godfrey HP, Kaplan AP. (1983) Histologic studies of chronic idiopathic urticaria. J. Allergy Clin. Immunol. 71: 177-183.

3. Greaves MW, Kaplan AP. (1988) Urticaria and angioedema. In: Samter $M$ (ed). Immunological Diseases, 4th ed., Vol. 2. Little, Brown, Boston, MA, pp. 1187-1204.

4. Hide M, Francis DM, Grattan CEH, Hakimi J, Kochan JP, Greaves MW. (1993) Autoantibodies against the high affinity IgE receptor as a cause of histamine release in chronic urticaria. N. Engl. J. Med. 328: 1599-1604.

5. Fiebiger E, Maurer D, Holub H, et al. (1995) Serum IgG autoantibodies directed against the $\alpha$ chain of FceRI: A selective marker and pathogenetic factor for a distinct subset of chronic urticaria patients? J. Clin. Invest. 96: 2606-2612.

6. Niimi N, Francis DM, Kermani $F$, et al. (1996) Dermal mast cell activation by autoantibodies against the high affinity IgE receptor in chronic urticaria. J. Invest. Dermatol. 106: 1001-1006.

7. Kaplan AP, Horakova Z, Katz SI. (1978) Assessment of tissue fluid histamine levels in patients with urticaria. J. Allergy Clin. Immunol. 61: 350-354.

8. Moncada S, Higgs EA. (1993) Nitric oxide, a review. N. Engl. J. Med. 329: 2002-2014.

9. Stuehr DJ, Griffith OW. (1992) Mammalian nitric oxide synthases. Adv. Enzymol. 65: 287-293.

10. Stamler JS, Singel DJ, Loscalzo J. (1992) Nitric oxide biochemistry. Science 258: $1898-$ 2014.

11. Moncada S, Palmer RMJ, Higgs EA. (1991) Nitric oxide: Physiology, pathophysiology and pharmacology. Pharmacol. Rev. 43: 109142.
12. Bécherel PA, Mossalayi MD, Ouaaz F, et al. (1994) Involvement of cyclic AMP and nitric oxide in immunoglobulin-dependent activation of FCERII/CD23 normal human keratinocytes. J. Clin. Invest. 93: 2275-2279.

13. Geller DA, Di Silvio $M$, Nüssler AK, et al. (1993) Nitric oxide synthase expression is induced in hepatocytes in vivo during hepatic inflammation. J. Surg. Res. 55: 427435.

14. KolbBachofen V, Fehsel K, Michel G, Ruzicka T. (1994) Epidermal keratinocyte expression of nitric oxide synthase in skin lesions of psoriasis vulgaris. Lancet 344: 139.

15. Rowe A, Farrel A, Kazmi SH, Bunker CB. (1994) Expression of an inducible nitric oxide synthase in dermal microvasculature in psoriasis. Lancet 344: 1371.

16. Goldsmith PC, Leslie TA, Hayes NA, Levell NJ, Dowd PM, Foreman JC. (1996) Inhibitors of nitric oxide synthase in human skin. J. Invest. Dermatol. 106: 113-118.

17. Bos JD, Kapsenberg ML. (1993) The skin immune system: Progress in cutaneous biology. Immunol. Today. 14: 75-80.

18. Luger TA, Schwarz T. (1990) TNF $\alpha$ and skin. In: Bos JD (ed). Skin Immune System. CRC Press, New York, pp. 65-78.

19. Bécherel PA, LeGoff L, Ktorza S, et al. (1995) Interleukin-10 inhibits IgE-mediated nitric oxide synthase induction and cytokine synthesis in normal human keratinocytes. Eur. J. Immunol. 25: 2992-2997.

20. Paul WE. (1991) Interleukin 4: A prototypic immunoregulatory lymphokine. Blood 77: 1859-1870.

21. Arock M, Merle-Béral H, Dugas B, et al. (1993) IL-4 release by human leukemic and activated normal basophils. J. Immunol. 151: 1441-149.

22. Bécherel PA, Mossalayi MD, LeGoff L, et al. (1994) Mechanism of anti-inflammatory action of retinoids on keratinocytes NO-synthase activation. Lancet 344: 1570-1571.

23. Mossalayi MD, Arock M, Delespesse G, et al. (1992) Cytokine effects of CD23 are mediated by an epitope distinct from the $\mathrm{IgE}$ binding site. EMBO J. 11: 3423-3428.

24. Lüdin C, Hofstetter H, Sarfati M, et al. (1987) Cloning and expression of the cDNA coding for a human lymphocyte IgE receptor. $E M B O$ J. 6: 109-114.

25. Held H, MacDonald HR, Weissman IL, Hess MW, Mueler C. (1990) Genes encoding tumor necrosis factor $\alpha$ and granzyme $\mathrm{A}$ are 
expressed during development of autoimmune diabetes. Proc. Natl. Acad. Sci. USA 87: 2239-2243.

26. Bosseloir A, Hooghe-Peters EL, Heinen E, et al. (1989) Localization of interleukin 6 mRNA in human tonsils by in situ hybridization. Eur. J. Immunol. 19: 2379-2381.

27. Green LC, Wagner DA, Glogowski PL, Skipper J, Wishnock JS, Tannenbaum SR. (1982) Analysis of nitrate and nitrite in biological fluids. Anal. Biochem. 126: 131-136.

28. Person MG, Zetterstrom O, Agrenius V, Ihre E, Gustafsonn LE. (1994) Single breath nitric oxide measurements in asthmatic patients and smokers. Lancet 343: 146-148.

29. Boughton-Smith NK, Evans SM, Hawkey CJ, et al. (1993) Nitric oxide synthase activity in ulcerative colitis and Crohn's disease. Lancet 342: 338-341.

30. Farrel AJ, Blake DR, Palmer RMJ, Moncada S. (1992) Increased concentrations of nitrite in synovial fluid and serum sample suggest increased nitric oxide synthesis in rheumatic diseases. Ann. Rheum. Dis. 51: 1219-1225.

31. Habib FM, Springall DR, Davies GL, Oakley CM, Yacoub MH, Polak JM. (1996) Tumour necrosis factor alpha and inducible nitric oxide synthase in dilated cardiomyopathy. Lancet 347: 1151-1155.

32. Moncada S, Higgs EA. (1995) Molecular mechanisms and therapeutic strategies related to nitric oxide. FASEB J. 9: 1319-1330.

33. Monroe EW. (1985) Chronic urticaria: Review of drug management. In: Champion RH, Greaves MW, Kobza Black A, Pye RJ (eds). The Urticarias. Churchill Livingstone, Edinburgh, pp. 205-211.

34. Bécherel PA, LeGoff L, Ktorza S, et al. (1996) CD23-mediated nitric oxide synthase pathway induction in human keratinocytes is inhibited by retinoic acid derivatives. J. Invest. Dermatol. 106: 1182-1186.

Communicated by S. Moncada. Accepted July 23, 1997. 